\title{
Recenzja książki Marcina Starnawskiego Socjalizacja i tożsamość żydowska w Polsce powojennej. Narracje emigrantów z pokolenia Marca '68. Wroctaw: Wydawnictwo Naukowe Dolnośląskiej Szkoły Wyższej 2016
}

\author{
Kaja Kaźmierska
}

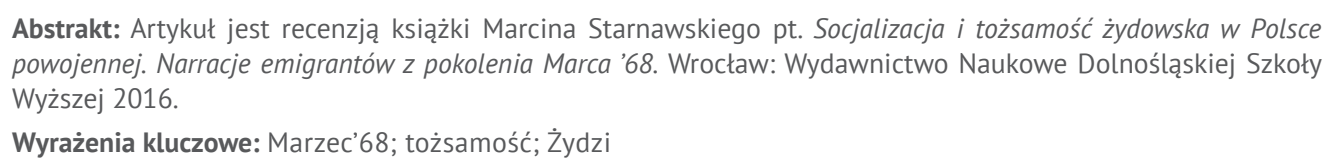

Abstrakt: Artykuł jest recenzją książki Marcina Starnawskiego pt. Socjalizacja i tożsamość żydowska w Polsce powojennej. Narracje emigrantów z pokolenia Marca '68. Wrocław: Wydawnictwo Naukowe Dolnośląskiej Szkoły Wyższej 2016.

Wyrażenia kluczowe: Marzec'68; tożsamość; Żydzi

Książka Marcina Starnawskiego to obszerna, licząca 418 stron monografia, poświęcona wciąż mało opracowanej problematyce Marca '68. Trudna powojenna historia Polski obfituje w wiele ważnych wydarzeń, które zaznaczyć można poprzez dokładny „punkt” w czasoprzestrzeni (np. Październik '56, Marzec '68, Grudzień '70, Sierpień '80 czy Grudzień '81) lub przez rozłożone w czasie procesy, na przykład doświadczenie PRL-u (niejednorodne, bo swoiste dla różnych okresów). W omawianej książce autor stara się uchwycić te dwa porządki, pokazując doświadczenie Marca '68 nie tylko jako punkt zwrotny w biografii jednostek (ale też całego społeczeństwa polskiego), lecz również jako jeden z elementów rozciągniętego w czasie procesu kształtowania się tożsamości indywidualnej i zbiorowej. Ta próba pokazania dynamiki zjawisk i procesów społecznych kształtujących jednocześnie procesy biograficzne (choć może nie do końca w książce udana) jest niewątpliwą zaletą tej publikacji. Drugą ważną cechą opracowania jest próba połączenia perspektywy socjologicznej z pedagogiczną. Autor z równie dobrym skutkiem prezentuje się i jako socjolog, i jako pedagog, potwierdzając to znajomością literatury przedmiotu i swobodą poruszania się na obu tych polach. Temperament pedagogiczny najbardziej widoczny jest chyba w zakończeniu, w którym niejako „porzuca” podstawowy przedmiot swoich rozważań - tożsamość żydowską w Polsce powojennej i konteksty Marca '68. Przedmiotem refleksji czyni społeczeństwo polskie, które powinno, po pierwsze, zmierzyć się z tym wydarzeniem poprzez pracę pamięci zbiorowej; po drugie, praca ta powinna służyć refleksji na przyszłość, tzn. być skierowana na kształtowanie tożsamości zbiorowej i postaw społecznych, w tym przede wszystkim relacji

SLH 8/2019 | str. 1 z 6 
wobec Innego, aby wydarzenia takie jak Marzec '68 nie mogły zaistnieć. Ich pojawianie się jest bowiem w mniejszym stopniu powodowane „zewnętrznym” impulsem, w większym zaś jest konsekwencją przechowywanych w pamięci zbiorowej i przekazywanych kolejnym generacjom kodów kulturowych, w których zapisane są m.in. obrazy Innych, źródła niechęci, stereotypy i uprzedzenia. Zastosowanie konkretnej „pedagogii”, jak pisze M. Starnawski, dając jej przykłady czy wręcz podsuwając konkretne kierunki jej rozwoju, powinno być nie tylko przedmiotem namysłu tych, którzy kształtują kolejne pokolenia, ale również pobudzać do refleksji wszystkich uczestników życia społecznego. To bardzo ciekawa propozycja, kojarząca się w moim odczuciu z refleksją Floriana Znanieckiego, który pisząc o człowieku przyszłości, nawiązywał do Sokratejskiej perspektywy i uznawał, iż człowiek ów powinien być przede wszystkim mądry i dobry.

Wróćmy teraz do początku książki, która składa się z siedmiu rozdziałów, wprowadzenia i wspomnianego już zakończenia. We wprowadzeniu autor przedstawia założenia pracy, charakteryzuje materiał badawczy, którego głównym trzonem jest 69 pogłębionych wywiadów swobodnych (przeprowadzonych w różnych krajach z emigrantami Marca '68), zawierających elementy wywiadu autobiograficznego. Przy czym autor wyraźnie stwierdza, że analiza biograficzna nie była jego celem, co najwyżej środkiem czy subelementem analizy, która miała skupiać się przede wszystkim na, jak pisze Starnawski, narracjach tożsamościowych. Przedstawiając przekonujące argumenty na rzecz bogactwa materiału, autor informuje czytelnika, iż jego analiza kończy się na momencie wyjazdu jego rozmówców z Polski - praca byłaby bowiem zbyt obszerna, gdyby zajął się i kolejnym etapem ich biografii. Po przeczytaniu całej książki uważam jednak, że nie była to dobra decyzja. Opracowanie również tej fazy życia w perspektywie procesów konstruowania tożsamości umożliwiłoby pokazanie całości tego procesu, który, jak wielokrotnie i słusznie pokazuje autor, jest efektem wielorakich czynników, a ponadto w zasadzie nigdy się nie kończy - tożsamość ciągle podlega procesowi rekonstrukcji. Idąc tym tropem, należy stwierdzić, że sposób prezentacji siebie z przeszłości uwarunkowany jest również tym, w jaki sposób jednostka postrzega się dzisiaj.

Druga wątpliwość, jaka rodzić się może po lekturze wprowadzenia, a potem całości, to sformułowanie „narracje tożsamościowe”. Trzeba przyznać, że Marcin Starnawski świetnie orientuje się w kwestiach teoretyczno-metodologicznych, odwołując się do różnych i rozlicznych źródeł. W tym kontekście dziwi nieco fakt, że w zasadzie nie znajdujemy wyjaśnienia, co autor rozumie pod stwierdzeniem „narracje tożsamościowe”. Czy są to spontanicznie pojawiające się $\mathrm{w}$ wywiadzie opowieści związane $\mathrm{z}$ poczuciem tożsamości, czy są one wywoływane konkretnymi pytaniami, wreszcie czy stwierdzenie to użyte jest jako metafora, gdyż bardzo wiele, jeśli nie większość, zacytowanych w książce wypowiedzi rozmówców to w istocie argumentacje, a nie narracje. Na koniec, w odniesieniu do uwag zawartych we wprowadzeniu można wyrazić lekkie rozczarowanie tym, że cytowane wypowiedzi służą przede wszystkim ilustracji pewnych tez, bardzo rzadko 
zaś stanowią przedmiot analizy jako takiej (autor deklaruje, że będzie wykorzystywał cytaty na obydwa sposoby).

Dwa pierwsze rozdziały stanowią teoretyczne wprowadzenie do badanej problematyki. Przedmiotem rozważań w rozdziale pierwszym są kwestie tożsamości kulturowej. Autor odwołuje się do wielu perspektyw teoretycznych i, moim zdaniem, mamy tu do czynienia z embarras de richesse, którego zwiastun widoczny jest już we wprowadzeniu. Myślę, że odnoszenie się do tak wielu sposobów ujmowania tożsamości, a przede wszystkim łączenie dość przeciwstawnych tradycji, np. perspektywy Bourdieu z socjologią interpretatywną, po pierwsze, nie jest przekonujące, a po drugie nie znajduje odzwierciedlenia w części analitycznej książki. Pojawia się tu wiele niespójności związanych, moim zdaniem, z próbą wykorzystania wielu (jeśli nie wszystkich) możliwości opisu rzeczywistości przez pryzmat problematyki tożsamości. Odwołam się tylko do jednego przykładu. Jeszcze we wprowadzeniu autor, deklarując zainteresowanie tożsamością jako centralnym tematem książki, odwołuje się do Zygmunta Baumana i jego diagnozy ambiwalencji tożsamości w dobie płynnej nowoczesności. Następnie za typowy przykład takiej ambiwalencji uznaje napięcia między kategoriami „narodu”, „grupy etnicznej” czy „ojczyzny” w odniesieniu do badanej grupy (Starnawski, 2016, s. 16-17). Otóż wydaje mi się, że, po pierwsze, kategorie te należą bardziej do porządku społeczeństwa nowoczesnego, a nie ponowoczesnego, po drugie zaś w tej konkretnej sytuacji dotyczącej tożsamości żydowskiej w Polsce powojennej - ambiwalencje mają swoje źródło nie w procesach ponowoczesnych, ale „klasycznych” ramach orientacyjnych do budowania tożsamości zbiorowych. Szkoda, że w kontekście tak bogatych odniesień do literatury przedmiotu autor pominął koncepcję człowieka marginalnego Roberta Parka i Everetta Stonequista, która daleko lepiej wyjaśniałaby źródła wskazywanej ambiwalencji.

Rozdział drugi to opis kontekstów społeczno-historyczno-kulturowych, które autor nazywa polem identyfikacyjnym dotyczących relacji polsko-żydowskich od połowy XIX wieku po lata sześćdziesiąte wieku XX. Stanowi on ciekawy przegląd owego pola, chociaż - jeśli weźmiemy pod uwagę objętość całej pracy (i wspomniany wcześniej brak opracowania wypowiedzi rozmówców dotyczący okresu po emigracji z Polski) - mógłby być krótszy. Istnieje bowiem wiele opracowań poświęconych tej problematyce, z których zresztą autor w tym rozdziale korzysta.

Od strony 167 rozpoczyna się analiza zebranego materiału (Starnawski, 2016, rozdziały III-VII). Jest to bardzo interesujący opis odnoszący się do kilku etapów/faz cyklu życia ukazanych w kontekście procesów społeczno-historyczno-politycznych. Marcin Starnawski umiejętnie łączy tu perspektywę mikro- i makrospołeczną, pokazując ich wzajemne interakcje. I tak w rozdziale trzecim omówione zostały czynniki makrospołeczne, różnicujące doświadczenia rozmówców poprzez status społeczny ich rodziców, miejsce zamieszkania - duże ośrodki miejskie czy też miejscowości, które po wojnie można by uznać za centra życia społeczności żydowskiej, stosunek do komuni- 
zmu i ustroju politycznego PRL, zwłaszcza pokolenia rodziców. Pokazanie rozmówców z tej perspektywy umożliwiło nie tylko charakterystykę ram społecznych, w których kształtowała się ich tożsamość, lecz również ukazało wewnętrzne zróżnicowanie społeczności żydowskiej, której często z pespektywy zewnętrznego oglądu przypisywano/ przypisuje się dość monolityczny, niejednokrotnie stereotypowy obraz. Kolejny rozdział zatytułowany Socjalizacja do „polskości” i „żydowskości” - zróżnicowanie identyfikacyjne zawiera ciekawą typologię. Autor wyróżnia „żydowskich Żydów”, „Żydów-Polaków”, „niewidocznych Żydów”, „no man’s land”. Mam jednak wątpliwości, dlaczego ramą dla tych identyfikacji ma być proces asymilacji, którą Starnawski definiuje jako „wrośnięcie w kulturę polską". Otóż mam wrażenie, że pojęcie to odnosiłoby się raczej do pokolenia (niektórych) rodziców rozmówców, oni zaś sami w wymiarze społeczno-kulturowym posiadali pełne kompetencje „polskości” niezależnie zresztą od stopnia identyfikacji z żydowskością. Krótko mówiąc, zarówno procesy zachodzące po wojnie wewnątrz społeczności żydowskiej (zwłaszcza tych, którzy nie wyjechali z Polski tuż po wojnie), jak i procesy dotyczące całego społeczeństwa polskiego, związane po części z ideologicznym zamysłem jego monoetnicznosci, po części z ideologicznym (choć nie do końca realizowanym w praktyce) egalitaryzmem, doprowadziły do tego, że (niezależnie od istniejących stereotypów i uprzedzeń) pokolenie rozmówców nie musiało się asymilować, gdyż posiadało pełne kompetencje kulturowe. Moje wątpliwości potwierdza rozdział piąty, w którym autor charakteryzuje „żydowskie zasoby tożsamościowe” i pokazuje nie tylko różnorodne źródła budowania tej identyfikacji, ale też pewien rodzaj „wysiłku” włożony w jej kultywowanie, konstruowanie, czy wręcz rekonstruowanie, wobec polskiej dominującej ramy społeczno-kulturowej. Ostatnie dwa rozdziały poświęcone są bezpośrednio doświadczeniom wydarzeń Marca '68. Marcin Starnawski stara się zrekonstruować tę fazę biografii respondentów, biorąc pod uwagę zarówno czynniki makrospoŁeczne, a wśród nich z jednej strony sytuację polityczną, z drugiej uaktywnienie antysemickich postaw, jak i poziom mikrospołeczny odnoszący się nie tylko do własnych doświadczeń rozmówców, lecz również do kolektywnego poczucia losu, transmisji przekazów rodzinnych i budowania paraleli między doświadczeniem przeszłości a teraźniejszości w stosunku do sytuacji definiowanej jako zagrożenie.

Tak jak zaznaczyłam na wstępie, autor nie zdecydował się na przedstawienie tej części wywiadów, które poświęcone są fazie po-emigracji, czyli współczesności, i powtórzę raz jeszcze, że wielka to szkoda. Historie rozmówców zostały w tym sensie ucięte, przerwane wraz z ich wyjazdem. Oczywiście można ten zamysł autora potraktować jako celowe urwanie, aby jeszcze bardziej wzmocnić biograficzne i społeczne znaczenie wydarzeń marcowych i wymóc $w$ ten sposób na czytelniku refleksję nad ich konsekwencjami, zwłaszcza że - jak napisałam na początku - w zakończeniu książki Marcin Starnawski zwraca się ku współczesnemu społeczeństwu polskiemu, a nie odnosi się w sposób bezpośredni do rozmówców. Z drugiej strony to ucięcie można też potraktować jako amputację pewnej części historii i w jakiejś mierze odebranie głosu rozmów- 
com. W wymiarze analitycznym uniemożliwia to pokazanie, jak/czy współczesna perspektywa, naznaczona migracją i konkretnymi doświadczeniami z nią związanymi (np. potrzebą asymilacji do innej kultury) wpłynęła na konstruowanie opowieści o wcześniejszych fazach biografii, w tym - jak mówi autor - narracji tożsamościowych; zwłaszcza że kilkakrotnie znajdujemy w książce deklarację o konstruktywistycznym podejściu do tożsamości. Muszę wreszcie podkreślić, a uwaga ta może płynąć z uprawianego przeze mnie podejścia biograficznego, że wybór tych kilku, oczywiście znaczących czy wręcz fundamentalnych punktów w biografii (omówionych w poszczególnych rozdziałach) nie do końca ukazuje procesualny charakter opisywanych zjawisk. Dużo lepiej ową dynamikę biograficzną, ale i społeczną, widać w książce Joanny Wiszniewicz Życie przecięte (Wiszniewicz, 2008), którą autor wspomina jako jedną z najważniejszych publikacji o tej problematyce, jednak w zasadzie w ogóle się do niej nie odnosi w części analitycznej i nie zamieszcza w bibliografii.

Reasumując, mimo moich uwag krytycznych, mimo tego, że momentami książka wymaga uwagi przy lekturze ze względu na zagęszczenie treści i niekiedy niepotrzebnie zbyt zawikłany język, jest to bardzo ciekawa i pouczająca praca. Należy ją polecić socjologom, pedagogom, historykom i to nie tylko tym, którzy profesjonalnie interesują się najnowszą historią społeczeństwa polskiego, lecz również tym (czyli zapewne większości z nas), którzy niewiele wiedzą o funkcjonowaniu społeczności żydowskiej w okresie PRL-u, a zwłaszcza o wydarzeniach Marca '68. W tym kontekście niezwykle cenne jest oddanie głosu rozmówcom (poprzez cytaty) oraz pokazanie różnorodności prezentowanych przez nich sposobów kształtowania tożsamości.

\section{Bibliografia}

Starnawski, M. (2016). Socjalizacja i tożsamość żydowska w Polsce powojennej: Narracje emigrantów z pokolenia Marca '68. Wrocław: Wydawnictwo Naukowe Dolnośląskiej Szkoły Wyższej.

Wiszniewicz, J. (2008). Życie przecięte: Opowieści pokolenia Marca. Wołowiec: Czarne.

A review of Marcin Starnawski’s Socjalizacja i tożsamość żydowska w Polsce powojennej: Narracje emigrantów z pokolenia Marca '68, Wrocław: Wydawnictwo Naukowe Dolnośląskiej Szkoły Wyższej 2016

Abstract: The article is a review of Marcin Starnawski’s Socjalizacja i tożsamość żydowska w Polsce powojennej: Narracje emigrantów z pokolenia Marca '68 [Jewish Socialization and Identity in Postwar Poland: Narratives of Émigrés from the March 1968 Generation], Wrocław: Wydawnictwo Naukowe Dolnośląskiej Szkoły Wyższej 2016.

Keywords: March 1968; identity; Jews 
Article No. 1759

DOI: $10.11649 /$ slh.1759

Citation: Kaźmierska, K. (2019). Recenzja książki Marcina Starnawskiego Socjalizacja i tożsamość żydowska w Polsce powojennej: Narracje emigrantów z pokolenia Marca '68, Wrocław: Wydawnictwo Naukowe Dolnośląskiej Szkoły Wyższej 2016. Studia Litteraria et Historica, 2019(8). https://doi.org/10.11649/1759

This is an Open Access article distributed under the terms of the Creative Commons Attribution 3.0 PL License, which permits redistribution, commercial and non-commercial, provided that the article is properly cited. http://www.creativecommons.org/licenses/by/3.0/pl (c) The Author(s) 2019

Publisher: Institute of Slavic Studies, Polish Academy of Sciences, Warsaw, Poland Author: Kaja Kaźmierska, University of Lodz, Łódź, Poland ORCID: https://orcid.org/0000-0002-9044-7273

Correspondence: kaja.kazmierska@uni.lodz.pl

The preparation of this work was self-financed by the author. Competing interests: The author has declared she has no competing interests. 